DEMOGRAPHIC RESEARCH

VOLUME 37, ARTICLE 2, PAGES 13-24

PUBLISHED 5 JULY 2017

http://www.demographic-research.org/Volumes/Vol37/2/

DOI: 10.4054/DemRes.2017.37.2

Editorial

\title{
Editorial for Special Collection on New Relationships from a Comparative Perspective
}

\section{Anne-Rigt Poortman}

\section{Belinda Hewitt}

This publication is part of the Special Collection on "New Relationships from a Comparative Perspective," organized by Guest Editors Anne-Rigt Poortman and Belinda Hewitt.

(C) 2017 Anne-Rigt Poortman \& Belinda Hewitt.

This open-access work is published under the terms of the Creative Commons Attribution NonCommercial License 2.0 Germany, which permits use, reproduction \& distribution in any medium for non-commercial purposes, provided the original author(s) and source are given credit.

See http://creativecommons. org/licenses/by-nc/2. 0/del 


\section{Contents}

1 Background of the special collection $\quad 14$

2 Contributions to the literature of the special collection 15

3 Content of the special collection 16

4 Descriptions of contributions to special collection 17

$\begin{array}{ll}\text { References } & 22\end{array}$ 


\title{
Editorial for Special Collection on New Relationships from a Comparative Perspective
}

\author{
In memory of Suzanne Bianchi
}

\author{
Anne-Rigt Poortman ${ }^{1}$
}

Belinda Hewitt ${ }^{2}$

\begin{abstract}
BACKGROUND

This special collection is the result of a collaboration between a group of family scholars from Europe and the United States. It initially developed from the observation that in many Western countries new types of couple relationships have emerged alongside marriage (i.e., cohabitation and living-apart-together [LAT] relationships). Although the trend seems universal, it is likely that the prevalence of different relationship types, and their outcomes in particular, vary across countries. Countries differ in how they institutionalize and confer meaning on new relationship types. Such differences may have important implications for how couples behave and organize their daily lives, in turn affecting the well-being of family members. The articles in this special collection aim to understand the organization and relationship outcomes of cohabitation, marriage, and LAT relationships across countries.
\end{abstract}

\section{CONTRIBUTION}

Although there has been an upsurge in cross-national research on new relationship types, most studies focus on cohabitation and less so on LAT relationships. In addition, most studies examine how new relationship types differ from marriage in demographic aspects (e.g., childbearing, union stability) or in terms of family members' well-being. Little cross-national evidence exists about differences with regard to how couples negotiate and give form to their relationship in their daily lives, or about dimensions that go beyond the relationship itself, such as people's relationships with their larger family. This special collection contributes to the existing body of knowledge by studying new relationships from a comparative perspective, looking at LAT

\footnotetext{
${ }^{1}$ Department of Sociology/ICS, Utrecht University, the Netherlands. E-Mail: a.poortman@uu.nl

${ }^{2}$ University of Melbourne, Australia.
} 
relationships as well as cohabitation, and examining how couples differ from each other on relationship dimensions that have been relatively understudied.

\section{Background of the special collection}

This special collection is the result of a collaboration between a group of family scholars from Europe and the United States. The group came together for the first time in 2009 in Utrecht, the Netherlands, where scholars were invited to present their work around the theme "Economic and social arrangements in couple relationships: Change and continuity from an international perspective." This was the start of a small informal network called Relations-Cross-Nations (RCN) that came together (nearly) each year to discuss and present new work and ideas about family relationships. Over the years, some members left the group and new members joined, but most people attending the first meeting in 2009 remained involved in the RCN. One of the people that was involved from the beginning was Suzanne Bianchi. She was one of the driving forces of the RCN and organized the 2012 workshop in Los Angeles. Sadly, Suzanne passed away in 2013. Losing her was significant for the group - we miss her enthusiasm and her curious, open, and analytical mind. We dedicate this special collection to Suzanne.

In putting together this collection, we started from the by now well-known observation that in many Western countries new types of couple relationships have emerged alongside marriage. Cohabitation and living-apart-together (LAT) relationships are the prime examples of such new relationship types. Although the trend seems universal, there is every reason to assume that the prevalence of different relationship types, and their outcomes in particular, vary across countries. Countries are likely to differ in how they institutionalize and confer meaning on new relationship types. For instance, in some countries the legal rights and obligations of cohabitors almost equal those of married couples, whereas in other countries cohabitors enjoy substantially fewer legal protections than married couples (Perelli-Harris and Gassen 2012). The social norms surrounding marriage, cohabitation, and LAT relationships also vary across countries (Gubernskaya 2010), which leads to varying degrees of institutionalization of these relationships (Cherlin 2004). Relatedly, cohabitation may have different meanings across countries, with cohabitation or LAT relationships being just a temporary phase in some countries and long-term relationship types in others (Heuveline and Timberlake 2004; Hiekel, Liefbroer, and Poortman 2014b). Such differences may have important implications for how couples behave and organize their daily lives, in turn affecting the well-being of family members. The articles in this 
special collection therefore aim to understand the organization and relationship outcomes of cohabitation, marriage, and LAT relationships across countries.

\section{Contributions to the literature of the special collection}

The majority of previous research on new relationships has been country-specific rather than comparative. Admittedly, there has been an upsurge in cross-national research in the past decade, but there are some notable limitations in the cross-national research examining new relationship types. Most cross-national research focuses on cohabitation while large-scale cross-national research on LAT relationships is scarce. Although there are some country-specific studies on LAT (e.g., Strohm et al. 2009; Castro-Martín, Domínguez-Folgueras, and Martín-García 2008; Régnier-Lollier, Beaujouan, and Villeneuve-Gokalp 2009), there is little comparative knowledge about the prevalence of LAT across countries. Also, little is known about country variation in the meaning of LAT relationships or whether LAT couples fare better or worse vis-à-vis couples in other relationship types. In addition, little cross-national evidence exists about how couples in new relationships differ from married couples with regard to how they negotiate and give form to their relationships in their daily lives. Most studies focus on cross-national differences in how cohabitation differs from marriage with respect to demographic aspects, such as childbearing or relationship outcomes, or in terms of family members' well-being (e.g., Perelli-Harris et al. 2010; Liefbroer and Dourleijn 2006; Soons and Kalmijn 2009). The few studies on how much couples in different relationship types differ in their division of paid and unpaid labor, financial arrangements, or social activities tend to be country-specific (e.g., Lyngstad, Noack, and Tufte 2011; Poortman and Mills 2012; Kalmijn and Bernasco 2001; Ciabattari 2004) or confined to a comparison of only few countries (Heimdal and Houseknecht 2003; Hamplova and Le Bourdais 2009). We know even less about cross-national differences between married people and those in other types of relationships when it comes to dimensions that go beyond the relationship itself, such as people's relationships with other family members such as siblings or parents (but see, e.g., Hogerbrugge and Dykstra 2009; Nazio and Saraceno 2013).

With this special collection we aim to contribute to the existing body of knowledge

by (i) studying new relationships from a comparative perspective, thus taking into account the specific context in which couples in diverse relationships make sense of their relation, (ii) looking at LAT relationships as well as cohabitation, and (iii) examining how couples differ from each other in aspects that have been relatively understudied. 


\section{Content of the special collection}

The special collection consists of three parts, with each part addressing a different aspect of cross-national variation in the organization and relationship outcomes of new relationships. The first part focuses on the broader cultural context that shapes people's relationship choices and their behavior within different relationships. The second part of the special collection deals with whether married and cohabiting couples differ in how they structure their relationship. The articles focus on a wide array of relatively understudied aspects of the internal organization of relationships, ranging from couples' financial arrangements to their use of contraceptives. The third part is dedicated to LAT relationships. Below we list the contributions to the special collection.

\section{Part 1: Changing attitudes toward new relationships}

Attitudes on marriage and new relationships: Cross-national evidence on the deinstitutionalization of marriage

Judith Treas, Jonathan Lui, Zoya Gubernskaya (SC19-2)

\section{Part 2: The organization of marriage and cohabitation}

Income pooling strategies among cohabiting and married couples: A comparative perspective

Nicole Hiekel, Aart C. Liefbroer, Anne-Rigt Poortman (SC19-3)

Disagreements among cohabiting and married couples in 22 European countries

Tanja van der Lippe, Marieke Voorpostel, Belinda Hewitt (SC19-4)

Children's union status and contact with mothers: A cross-national study Jenjira Yahirun, Dana Hamplová (SC19-5)

The reproductive context of cohabitation in comparative perspective: Contraceptive use in the United States, Spain, and France Megan Sweeney, Teresa Castro Martín, Melinda Mills (SC19-6)

Gender and time allocation of cohabiting and married women and men in France, Italy, and the United States

Suzanne Bianchi, Laurent Lesnard, Tiziana Nazio, Sara Raley (SC19-7) 


\section{Part 3: Living apart together}

Why do intimate partners live apart? Evidence on LAT relationships across Europe Aart C. Liefbroer, Anne-Rigt Poortman, Judith Seltzer (SC19-8)

Do co-residence and intentions make a difference? Relationship satisfaction in married, cohabiting, and living-apart-together couples in four countries Tsui-o Tai, Janeen Baxter, Belinda Hewitt (SC19-9)

\section{Descriptions of contributions to special collection}

The contribution by Treas, Lui, and Gubernskaya (2014, SC19-2) examines changes in attitudes toward marriage and nonmarital relationships between 1998 and 2008 across 21 countries. Their analysis includes more countries and a broader array of attitude items than previous work. The paper gives insight into whether the "deinstitutionalization of marriage" (Cherlin 2004) is universal or whether marriage norms remain strong in some countries. Overall, their results offer mixed support for the deinstitutionalization hypothesis. Findings are inconclusive when it comes to attitudes and expectations of behaviors within marriage, with some attitudes showing little change and other attitudes becoming more (wife's employment) or less (extramarital sex) approving. Acceptance of and attitudes toward nonmarital family arrangements have, however, become more tolerant. Cross-national variation was found in attitudes toward marriage and nonmarital relationships and for the observed changes in attitudes over time. The authors conclude that it is premature to conclude that marriage has become deinstitutionalized and that a careful and more refined conceptualization and more empirical research is needed.

The paper by Hiekel, Liefbroer, and Poortman (2014a, SC19-3) examines financial arrangements in cohabiting and married couples. Their study goes beyond previous work by including countries from Central and Eastern Europe in their analysis. In addition, they not only explain differences between cohabiters and married couples by differential selection into cohabitation but also by varying levels of commitment. Consistent with previous research, they find that cohabiters are less inclined to pool income, even after selection factors and differences in interpersonal commitment are taken into account. Patterns differ between Central and Eastern European countries and Western European countries, however. Not only are differences in money management between cohabiting and married couples more pronounced in Western European countries, but selection and commitment are also often found to be stronger predictors of independent money management in Western than in Central and Eastern European 
countries. The authors explain these country differences by referring to distinct economic and cultural conditions in Eastern and Western Europe, which challenges the conceptualization of money management as a matter of preference.

Van der Lippe, Voorpostel, and Hewitt (2014, SC19-4) look at the dark side of relationships. In contrast to most other work focusing on differences in positive aspects of couples' relationships (e.g., relationship satisfaction) between cohabiting and married couples, they focus on differences in conflicts and disagreements. Using data on 22 countries, they find disagreements differ between cohabiting and married couples, but the precise pattern depends upon the source of the conflict. While cohabiters do not differ from married couples in their disagreements about money, cohabiters have more conflicts about housework but fewer conflicts about paid work than married couples. The authors argue that these findings may be best explained by differences in gender role attitudes: Cohabitors value gender equality more than married couples, and because the actual division of housework in cohabiting relationships is often not in line with gender-egalitarian attitudes, cohabiters disagree more on this issue than married couples. The reverse holds for paid work. Interestingly, the authors find no genderbased or cross-national variation in the association between union type and conflicts. The authors suggest smaller-scale cross-national research to identify contextual factors possibly related to patterns of disagreements in cohabiting and married relationships.

The contribution by Yahirun and Hamplová (2014, SC19-5) extends existing research by focusing on variations in intergenerational contact between married, cohabiting, and single persons across 15 European countries. They find that relationship choices have implications for intergenerational contact. In all studied countries, cohabiters have less contact with their mothers than single persons. However, the gap in intergenerational contact between cohabiters and married persons and that between married and single persons is shaped by country context. In countries with weak family systems and a high prevalence of cohabitation (e.g., Northern European countries) married persons have less contact with their mothers than singles, whereas differences between cohabiters and married persons are often small. In contrast, in countries with strong family systems, where cohabitation is still marginalized (e.g., Southern Europe), married individuals have higher contact levels than either singles or cohabiters. The authors argue that cultural variations and differences in the prevalence of cohabitation associated with the strength of family systems are likely sources of these country differences.

Sweeney, Castro Martín, and Mills (2015, SC19-6) study differences in contraceptive use between cohabiting and married women. Contraceptive use is relatively understudied in research comparing and contrasting cohabitation and marriage, especially for European countries. According to the authors, this is surprising because the availability of effective contraceptives is often considered to be a driving 
force behind the rise in cohabitation. According to this line of reasoning, cohabiting women are expected to use more effective methods than married women, but differences are likely to be less pronounced in countries where cohabitation is more widespread and an alternative to marriage. Sweeney and colleagues study differences and trends in three countries that differ strongly in the prevalence and meaning of cohabitation. Cohabiting women are more likely to use more effective, but reversible, contraceptive methods than married women in France and the United States - and in France, these differences diminished somewhat over time. Spain, however, was found to be an exception: Cohabiting and married women did not differ much in their contraceptive use, and there was little change over time. The authors interpret these findings as a sign that not all countries fit the idea that the rise in cohabitation takes place in consecutive stages, from being a marginal, childless type of relationship to a relationship nearly indistinguishable from marriage involving children.

The paper by Bianchi, Lesnard, Nazio, and Raley (2014, SC19-7) examines whether the time spent on paid work, nonmarket work, and childcare differs between cohabiting men and women on the one hand and married men and women on the other. Only few previous studies have examined differences in time allocation, and this article goes beyond previous work by making a cross-national comparison between countries that differ strongly in the extent to which marriage is legally supported and distinct from cohabitation. As expected, given the fewer legal protections should cohabiting relationships dissolve, Bianchi and colleagues find a more equal division of time allocated to market and nonmarket work for men and women in cohabiting relationships compared to married men and women. Nevertheless, country differences were not consistently found on the basis of legal cross-national variation, with Italy having greater gender disparities than the United States or France. Interestingly, whereas time spent on nonmarket work (e.g., housework, shopping) is often less for cohabiting men and women than their married counterparts, especially in Italy, childcare is positively related to cohabiting in France and Italy. The authors argue that these mixed results suggest that the legal context may only be part of the story and that economic factors, social approval, and behavioral norms surrounding cohabitation - as well as the associated self-selection into cohabitation - are also likely to contribute to crossnational variation in time allocation differences between cohabiting and married persons.

The last two contributions (SC19-8 and SC19-9) go beyond the marriage and cohabitation dichotomy and include LAT relationships. The contribution by Liefbroer, Poortman, and Seltzer (2015, SC19-8) examines the prevalence of different types of LAT relationships and the correlates of LAT across Europe. Their article builds upon the relatively sparse body of research on LATs by considering not only couples (LAT, married, or cohabiting) in their analyses but also people who are single. In addition, 
they study both Western and Eastern European countries. LAT is found to be a relatively rare relationship state, but it is more common in Western than Eastern European countries. The majority of people in LAT relationships intend to live together, and practical reasons are most often mentioned for why people did not live together. Furthermore, financial constraints and life stage are among the most important correlates of LAT. More highly educated people, those with liberal attitudes, and divorced or widowed people are also more often in LAT relationships. Educational and attitudinal differences are more pronounced in Eastern than Western European countries. The authors tentatively conclude that LAT is mostly a stage in the union formation process. For some groups, however, LAT is an alternative to marriage and cohabitation, but these groups differ between Eastern and Western European countries: In Eastern Europe it is the liberal, highly educated elite, whereas it is older and previously married people in Western Europe.

The final paper in the collection, the contribution by Tai, Baxter, and Hewitt (2014, SC19-9), examines relationship satisfaction of those in LAT relationships compared to cohabitation and marriage from a cross-national perspective. Few studies have examined relationship outcomes of LAT relationships vis-à-vis coresidential relationships, and this article builds upon prior work by also taking the heterogeneity within LAT relationships into account. Similar to research on cohabitation, the authors distinguish different types of LAT by looking at people's intentions to marry or live together. Overall, married people have the highest level of relationship satisfaction, and those in LAT relationships are least satisfied. Intentions to marry or live together are also important, with people living in LAT relationships without intentions to marry or live together being the least satisfied. Patterns vary depending on country context, where countries with higher levels of social support for nonmarital unions have the smallest differences in relationship satisfaction across union types. The authors conclude that LAT relationships are a qualitatively different type of union than marriage or cohabitation and that future research should take LAT relationships into account more often.

All together, this collection indicates that perceptions and attitudes toward nonmarital relationships are becoming more tolerant across many countries. However, evidence on the strength of marriage norms is mixed, and important differences in the conduct and negotiation of new relationships - as compared to marriage - are also apparent. In most countries, married people are found to be more likely to pool their money and have lower levels of gender equality and higher levels of relationship satisfaction than those in new relationships types. For other relationship aspects differences between the different relationship types are less clear-cut (e.g., disagreements) or their nature strongly depends upon the country context (e.g., intergenerational contact, contraceptive use). LAT relationships are found to be 
qualitatively distinct from both marriage and cohabitation, but LAT is relatively rare and most often a temporary stage in the union formation process. 


\section{References}

Bianchi, S., Lesnard, L., Nazio, T., and Raley, S. (2014). Gender and time allocation of cohabiting and married women and men in France, Italy, and the United States. Demographic Research 31(8): 183-216. doi:10.4054/DemRes.2014.31.8.

Castro-Martín, T., Domínguez-Folgueras, M., and Martín-García, T. (2008). Not truly partnerless: Non-residential partnerships and retreat from marriage in Spain. Demographic Research 18(16): 443-468. doi:10.4054/DemRes.2008.18.16.

Cherlin, A.J. (2004). The deinstitutionalization of American marriage. Journal of Marriage and Family 66(4): 848-861. doi:10.1111/j.0022-2445.2004.00058.x.

Ciabattari, T. (2004). Cohabitation and housework: The effects of marital intentions. Journal of Marriage and Family 66(1): 118-125. doi:10.1111/j.00222445.2004.00008.x-i1.

Gubernskaya, Z. (2010). Changing attitudes toward marriage and children in six countries. Sociological Perspectives 53(2): 179-200. doi:10.1525/sop.2010.53.2. 179 .

Hamplova, D. and Le Bourdais, C. (2009). One pot or two pot strategies? Income pooling in married and unmarried households in comparative perspective. Journal of Comparative Family Studies 40(3): 355-385.

Heimdal, K.R. and Houseknecht, S.K. (2003). Cohabiting and married couples' income organization: Approaches in Sweden and the United States. Journal of Marriage and Family 65(3): 525-538. doi:10.1111/j.1741-3737.2003.00525.x.

Heuveline, P. and Timberlake, J.M. (2004). The role of cohabitation in family formation: The United States in comparative perspective. Journal of Marriage and Family 66(5): 1214-1230. doi:10.1111/j.0022-2445.2004.00088.x.

Hiekel, N., Liefbroer, A.C., and Poortman, A.-R. (2014a). Income pooling strategies among cohabiting and married couples: A comparative perspective. Demographic Research 30(55): 1527-1560. doi:10.4054/DemRes.2014.30.55.

Hiekel, N., Liefbroer, A.C., and Poortman, A.-R. (2014b). Understanding diversity in the meaning of cohabitation across Europe. European Journal of Population 30(4): 391-410. doi:10.1007/s10680-014-9321-1.

Hogerbrugge, M.J. and Dykstra, P.A. (2009). The family ties of unmarried cohabiting and married persons in the Netherlands. Journal of Marriage and Family 71(1): 135-145. doi:10.1111/j.1741-3737.2008.00585.x. 
Kalmijn, M. and Bernasco, W. (2001). Joint and separated lifestyles in couple relationships. Journal of Marriage and Family 63(3): 639-654. doi:10.1111/ j.1741-3737.2001.00639.x.

Liefbroer, A.C. and Dourleijn, E. (2006). Unmarried cohabitation and union stability: Testing the role of diffusion using data from 16 European countries. Demography 43(2): 203-221. doi:10.1353/dem.2006.0018.

Liefbroer, A.C., Poortman, A.-R., and Seltzer, J. (2015). Why do intimate partners live apart? Evidence on LAT relationships across Europe. Demographic Research 32(8): 251-286. doi:10.4054/DemRes.2015.32.8.

Lyngstad, T.H., Noack, T., and Tufte, P.A. (2011). Pooling of economic resources: A comparison of Norwegian married and cohabiting couples. European Sociological Review 27(5): 624-635. doi:10.1093/esr/jcq028.

Nazio, T. and Saraceno, C. (2013). Does cohabitation lead to weaker intergenerational bonds than marriage? A comparison between Italy and the United Kingdom. European Sociological Review 29(3): 549-564. doi:10.1093/esr/jcr103.

Perelli-Harris, B. and Gassen, N.S. (2012). How similar are cohabitation and marriage? Legal approaches to cohabitation across western Europe. Population and Development Review 38(3): 435-467. doi:10.1111/j.1728-4457.2012.00511.x.

Perelli-Harris, B., Sigle-Rushton, W., Kreyenfeld, M., Lappegård, T., Keizer, R., and Berghammer, C. (2010). The educational gradient of childbearing within cohabitation in Europe. Population and Development Review 36(4): 775-801. doi:10.1111/j.1728-4457.2010.00357.x.

Poortman, A.-R. and Mills, M. (2012). Investments in marriage and cohabitation: The role of legal and interpersonal commitment. Journal of Marriage and Family 74(2): 357-376. doi:10.1111/j.1741-3737.2011.00954.x.

Régnier-Lollier, A., Beaujouan, E., and Villeneuve-Gokalp, C. (2009). Neither single, nor in a couple: A study of living apart together in France. Demographic Research 21(4) 75-108. doi:10.4054/DemRes.2009.21.4.

Soons, J.P. and Kalmijn, M. (2009). Is marriage more than cohabitation? Well-being differences in 30 European countries. Journal of Marriage and Family 71(5): 1141-1157. doi:10.1111/j.1741-3737.2009.00660.x.

Strohm, C.Q., Seltzer, J.A., Cochran, S.D., and Mays, V.M. (2009). 'Living apart together' relationships in the United States. Demographic Research 21(7): 177214. doi:10.4054/DemRes.2009.21.7. 
Sweeney, M., Castro Martín, T., Mills, M. (2015). The reproductive context of cohabitation in comparative perspective: Contraceptive use in the United States, Spain, and France. Demographic Research 32(5): 147-182. doi:10.4054/Dem Res.2015.32.5.

Tai, T., Baxter, J., and Hewitt, B. (2014). Do co-residence and intentions make a difference? Relationship satisfaction in married, cohabiting, and living apart together couples in four countries. Demographic Research 31(3): 71-104. doi:10.4054/DemRes.2014.31.3.

Treas, J., Lui, J., and Gubernskaya, Z. (2014). Attitudes on marriage and new relationships: Cross-national evidence on the deinstitutionalization of marriage. Demographic Research 30(54): 1495-1526. doi:10.4054/DemRes.2014.30.54.

van der Lippe, T., Voorpostel, M., and Hewitt, B. (2014). Disagreements among cohabiting and married couples in 22 European countries. Demographic Research 31(10): 247-274. doi:10.4054/DemRes.2014.31.10.

Yahirun, J. and Hamplová, D. (2014). Children's union status and contact with mothers: A cross-national study. Demographic Research 30(51): 1413-1444. doi:10.40 54/DemRes.2014.30.51. 